\title{
Development and evaluation of models to estimate body chemical composition of young Nellore bulls
}

\author{
Luiz Henrique Oliveira Silva ${ }^{1}$, Sarah Figueiredo Martins Bonilha ${ }^{1 *}$, Renata Helena Branco1, \\ Joslaine Noely dos Santos Gonçalves Cyrillo', Maria Eugênia Zerlotti Mercadante ${ }^{1}$
}

${ }^{1}$ Instituto de Zootecnia, Centro APTA Bovinos de Corte, Sertãozinho, SP, Brazil.

\begin{abstract}
The objective of this study was to develop accurate regression equations to predict body composition of Nellore cattle using chemical composition of the 9th, 10th, and 11th ribs and to evaluate the models proposed by analyzing mean and linear bias. Sixty-seven Nellore bulls were slaughtered and slaughter body weight (SBW), hot carcass weight (HCW), and 9th-, 10th-, and 11th-rib-cut weight (RCW) were measured. Empty body composition was obtained after grinding, homogenizing, sampling, chemical analysis, and pooling (blood, skin, head + feet, viscera, and carcass). Chemical components were determined in rib cut, carcass, and empty body: protein (RCP, HCP, and EBP), fat (RCF, HCF, and EBF), ash (RCA, HCA, and EBA), and water (RCWt, HCWt, and EBWt). Stepwise options were used to determine variables to be included and excluded from regressions. Predictive ability of equations was verified using standard error of prediction, coefficient of determination, and $\mathrm{Cp}$ statistic. Regression estimates were tested to evaluate the models in a database different from that used for equation development. The best equations found to predict carcass components, in $\mathrm{kg}$, were: $\mathrm{HCF}=-0.994+0.123 \times \mathrm{SBW}-9.201 \times \mathrm{RCW}+34.249 \times$ $\mathrm{RCF}\left(\mathrm{R}^{2}=0.86\right)$ and $\mathrm{HCWt}=2.733-0.172 \times \mathrm{SBW}+0.821 \times \mathrm{HCW}-23.939 \times \mathrm{RCF}+12.186 \times \mathrm{RCWt}\left(\mathrm{R}^{2}=0.96\right)$. For empty body, the best equations, in $\mathrm{kg}$, were: $\mathrm{EBF}=-1.4+0.166 \times \mathrm{SBW}-10.073 \times \mathrm{RCW}+40.202 \times \mathrm{RCF}\left(\mathrm{R}^{2}=0.90\right)$ and $\mathrm{EBWt}=3.524$ $+0.272 \times \mathrm{SBW}+0.373 \times \mathrm{HCW}-11.727 \times \mathrm{RCW}+31.079 \times \mathrm{RCWt}\left(\mathrm{R}^{2}=0.98\right)$. Body weight has a high predictive power and should be included in equations to estimate body composition of Nellore cattle. Unbiased models are valid as an indirect method for determining body composition in beef cattle.
\end{abstract}

Key Words: beef cattle, feedlot, indirect determination

\section{Introduction}

Determining the body composition of beef cattle permits to study nutritional requirements and efficiency, as well as evaluate performance based on the production of carcasses with good cut yields and adequate amounts of fat in an attempt to reduce the age of the animals at slaughter. Different methods are available to determine the body composition of cattle, being the direct method the most accurate. However, this method is very time-consuming and expensive, since it requires the homogenization and sampling of all body organs and tissues and the analysis

Received: July 29, 2016

Accepted: November 6, 2016

*Corresponding author: sbonilha@iz.sp.gov.br

http://dx.doi.org/10.1590/S1806-92902017000200011

How to cite: Silva, L. H. O.; Bonilha, S. F. M.; Branco, R. H.; Cyrillo, J. N. S. G. and Mercadante, M. E. Z. 2017. Development and evaluation of models to estimate body chemical composition of young Nellore bulls. Revista Brasileira de Zootecnia 46(2):156-166.

Copyright (c) 2017 Sociedade Brasileira de Zootecnia. This is an Open Access article distributed under the terms of the Creative Commons Attribution License (http://creativecommons.org/licenses/by/4.0/), which permits unrestricted use, distribution, and reproduction in any medium, provided the original work is properly cited. of their chemical components. Consequently, noninvasive methods have been preferred due to their greater practicality and lower cost (De Paula et al., 2013). The indirect method most widely used for the determination of carcass and empty body composition, proposed by Hankins and Howe (1946), uses the composition of the 9th, 10th, and 11th rib section of animals to develop prediction models.

Accurate prediction models are necessary to correctly estimate the body composition of cattle. Models developed by stepwise regression provide linear equations using a specific criterion to determine the order in which variables should be included or removed (Efroymson, 1960). After choosing the variables, the next step is to select the best prediction models using criteria, such as the coefficient of determination $\left(\mathrm{R}^{2}\right)$ and Mallows' $\mathrm{Cp}$ statistic (MacNeil, 1983). Finally, the models selected need to be evaluated to verify the existence of prediction bias. Bias measures how far off the predictions of a model are from the observed values and, therefore, serves to determine the accuracy of a model (St-Pierre, 2003).

In view of the above considerations, the objectives of the present study were to develop precise and accurate models to predict the body composition of young Nellore 
bulls and apply these models to a second database to verify the existence of prediction bias.

\section{Material and Methods}

The experimental procedures followed guidelines of animal welfare and humane slaughter and were conducted in accordance with State Law No. 11.977 of São Paulo, Brazil.

A genetic selection program of the Nellore breed began in 1976 in the Instituto de Zootecnia research unit at the Centro APTA Bovinos de Corte. Control and selected lines were established, using bulls with a high selection differential for yearling weight for selected Nellore group and bulls with a selection differential for yearling weight around zero for control Nellore group. Cows and heifers available for breeding in the beginning of the program were randomly assigned to either the selected or the control groups. The program is in progress and the animals evaluated in this study are from the 26th and 27th calf crops of the program.

Sixty-seven Nellore bulls from both selected and control lines were used in two different trials: 33 animals were slaughtered in 2008 (trial 1) and 34 in 2009 (trial 2).

The animals were housed in individual pens throughout the experimental period determined by the time necessary for the animals to reach a subcutaneous fat thickness of $4 \mathrm{~mm}$ when they were slaughtered. The animals were randomly divided into three groups: baseline group, in which the animals were slaughtered after a period of adaptation (eight animals in trial 1 and eight animals in trial 2); restricted-feeding group, in which the animals had a daily feed intake of $65 \mathrm{~g}$ dry matter $/ \mathrm{kg}$ metabolic weight (nine animals in trial 1 and nine animals in trial 2); group in which the animals had ad libitum access to feed (16 animals in trial 1 and 17 animals in trial 2).

The diet of each trial was balanced with Brachiaria brizantha hay, ground corn, cottonseed, cottonseed meal, citrus pulp, and mineral mixture at a roughage:concentrate ratio of 19:81 on dry matter basis, containing $141 \mathrm{~g} / \mathrm{kg}$ crude protein and $820 \mathrm{~g} / \mathrm{kg}$ total digestible nutrients.

The slaughter occurred at a proportion of two ad libitum animals per restricted-feeding animal, i.e., when two ad libitum animals reached the slaughter criterion of $4 \mathrm{~mm}$ of subcutaneous fat thickness, they were slaughtered together with one randomly chosen restricted-feeding animal. The animals were slaughtered at an experimental slaughterhouse according to the usual procedures of humane slaughter.

After weighing, the animals were sent to the slaughter line, where they were restrained and stunned by cerebral concussion with a captive bolt pistol, hung by the left hind leg, and bled through cutting of the jugular vein. All blood was collected at the time of bleeding and weighed and blood samples were collected into properly identified glass containers and frozen until the time of chemical analysis. After bleeding, the animals were skinned, gutted, and halved. The skin was weighed and divided in half. Only the left half was used, which was chopped into squares of approximately $9 \mathrm{~cm}^{2}$ and ground for chemical analysis of centesimal composition. The organs were weighed, stored in plastic bags, and frozen. The digestive tract was also weighed, cleaned, and weighed again. The organ weights were added to the weight of the clean digestive tract and to the weights of the other body parts (carcass, head, skin, tail, legs, and blood) for the determination of empty body weight. After trimming and washing, the half-carcasses were cooled in the chill room at $2{ }^{\circ} \mathrm{C}$ for $24 \mathrm{~h}$. After this period, the carcasses were deboned and the tissues (soft tissues and bones) were stored in plastic bags and frozen.

The tissues frozen after slaughter were processed for direct determination of centesimal composition of the empty body and carcass, including grinding, sampling, chemical analyzing, and pooling all tissues of the animal.

The 9th-, 10th-, and 11th-rib section was separated from the left half-carcass according to Hankins and Howe (1946). The ribs were ground and sampled for chemical analysis of centesimal composition. Blood samples were collected during the slaughter procedures and frozen. The chopped left half of the skin was ground several times for homogenization and then sampled. The remaining components of the empty body (left half of the head + left legs, all viscera, and left half-carcass) were frozen, serrated into smaller pieces to avoid any loss of tissue, and ground several times until reduced to a pasty state.

Four samples of approximately $50 \mathrm{~g}$ each were removed from all tissues (ribs, blood, skin, head + legs, viscera, and carcass) and lyophilized for about $80 \mathrm{~h}$, the time necessary to reach a constant weight. After this period, the samples were reduced to smaller pieces, ground in a blender with dry ice to become a powder, identified, and stored in a freezer until the time of chemical analysis.

The contents of water, ether extract, protein, and ash were measured. Water content was determined by lyophilization and corrected for dry matter, analyzed in an oven at $105{ }^{\circ} \mathrm{C}$. For the determination of ether extract content, approximately $2 \mathrm{~g}$ of the samples stored in cartridges of qualitative filter paper were subjected to extraction for $3 \mathrm{~h}$ (drip rate of five to six drops/second). Extraction was performed according to the method of the AOCS (AOCS, 2009) in an XT15 extractor $\left(\right.$ Ankom $\left.^{\circledR}\right)$ 
using petroleum ether. Ash content was determined by burning approximately $2 \mathrm{~g}$ of the samples in a muffle furnace at $600{ }^{\circ} \mathrm{C}$ for $4 \mathrm{~h}$. Protein content was obtained by subtracting the ether extract, water, and ash content from $100 \%$.

The statistical analyses were performed using the SAS software (Statistical Analysis System, version 9.2). The normality of all variables was tested. The PROC MEANS was used for descriptive statistics and Pearson's linear correlation coefficients were calculated using the PROC CORR. Multiple linear regression models were developed with the PROC GLMSELECT to estimate the water, fat, protein, and ash composition of the carcass and empty body, in kilogram and percentage, considering slaughter and carcass weights and rib cut chemical composition as independent variables. Additionally, models were developed to estimate the water, fat, protein, and ash composition of the carcass and empty body, in kilogram and percentage, considering the physical composition of the rib section (muscle, fat, and bones).

Outliers were tested by regression of studentized residuals on the values predicted with a model that included all parameters. The data were removed when the studentized residual was situated outside the range of -2 to 2 . Next, the models were constructed by bidirectional stepwise elimination, in which the parameters are included or excluded one by one. The P-value was used to determine the variables that would enter and remain in the model. The P-value should be $<0.05$ for a variable to be included in the model and $<0.01$ for the variable to remain in the model. Mallows' Cp statistic (Mallows, 1973), coefficient of determination $\left(\mathrm{R}^{2}\right)$, and standard error of prediction were used as selection criteria of the best model.

A second database derived from 36 Nellore bulls, which also belonged to the Instituto de Zootecnia and had been slaughtered at a similar weight and age as the animals of the present study, was used for evaluation of the developed models. The chemical composition of the empty body, carcass, and rib cut of these animals was also determined using the direct method.

The best models were identified by regressing residuals on the predicted values centered on their respective means (St-Pierre, 2003) using the PROC REG. In this case, centralization of the independent variable around its mean renders the intercept and angular coefficient orthogonal and, consequently, independent of one another, assuming values of $\beta_{0}=0$ and $\beta_{1}=0$ when the model is unbiased. The intercept of the equation was used to estimate the mean bias, while linear bias was evaluated by the slope of the regression line. The equation tested was considered valid, i.e., without mean or linear bias, when the intercept and angular coefficient were statistically equal to zero, i.e., nonsignificant $(\mathrm{P}>0.05)$ by the $\mathrm{t}$-test.

\section{Results}

The wide range of variation in slaughter body weight and, consequently, in rib weight, hot carcass weight, and empty body weight (Table 1), was mainly due to three reasons: the use of a baseline group of animals, which were slaughtered immediately after the adaptation period and not finished to the standardized fat thickness; the use of animals belonging to different selection lines of Centro Avançado de Pesquisas Tecnológicas do Agronegócio de Bovinos de Corte. At present, the genetic differences between groups are expressive and, thus, wide variability exists in the size and maturity of the animals between the two selection lines used; and the different feeding regimens used during the experiment (ad libitum and restricted feeding). It is important to point out that all of these variations which, in principle, lead to the lack of experimental homogeneity, are relevant so that the regression models developed in this study can be applied to the different physiological, genetic, and feed conditions that can occur.

Slaughter body weight, carcass weight, and empty body weight were positively and highly correlated with the chemical components of the carcass and empty body, expressed as kilogram (Table 2). The correlations between the chemical components of the rib and their direct corresponding components in the carcass, in kilogram, were higher for protein, fat, and water. In contrast, carcass ash had a higher correlation with rib fat. When expressed as a percentage, strong correlations were only observed between water and fat content of the carcass and rib, with an inverse correlation between fat and water content.

The correlations between the amount of rib chemical components and the amount of empty body chemical components were positive in all cases when the variables were expressed as kilogram (Table 2). However, only rib fat and water exhibited a high correlation $(r>0.75)$ with their direct corresponding components in the carcass and empty body. When expressed as a percentage, the highest correlation coefficient $(\mathrm{r}=0.811)$ was observed between rib fat content and empty body fat content. However, this correlation coefficient was lower when the same components expressed as kilogram were correlated $(\mathrm{r}=0.837)$.

Ash content of the carcass and empty body was better correlated with rib muscle content $(\mathrm{r}=0.516)$ than with rib bone content $(r=0.459)$ (Table 3$)$. The amount of muscle in the rib showed a higher correlation coefficient with empty 
body protein content $(\mathrm{r}=0.800)$ than with carcass protein content $(r=0.484)$. In addition, the amount of muscle in the rib also exhibited an important correlation with carcass and empty body water content, as expected, since muscle tissue consists mainly of water. The correlations between carcass and empty body chemical composition and muscle, adipose tissue, and bone contents were generally close to zero.

Simple and multiple linear regression models were developed to predict the carcass and empty body chemical composition from the chemical composition of the rib and weight components, in kilogram and percentage, and from the physical composition of rib muscle, adipose tissue, and bones, in kilogram and percentage. The best equations obtained to predict the ash, protein, fat, and water contents of the carcass (Table 4) and empty body (Table 5) were those using the dependent and independent variables expressed as kilogram. In general, the equations whose dependent and independent variables were expressed as a percentage had lower coefficients of determination, eliminating the possibility of using these equations.

All models selected to estimate carcass and empty body chemical composition were applied to a second database (Bonilha et al., 2007) derived from 36 Nellore bulls that also belonged to Instituto de Zootecnia. These animals were slaughtered at a similar body weight and age (Table 6) as the animals of the present study and their chemical composition

Table 1 - Mean, standard deviation, and minimum and maximum values of the variables used for construction of the models

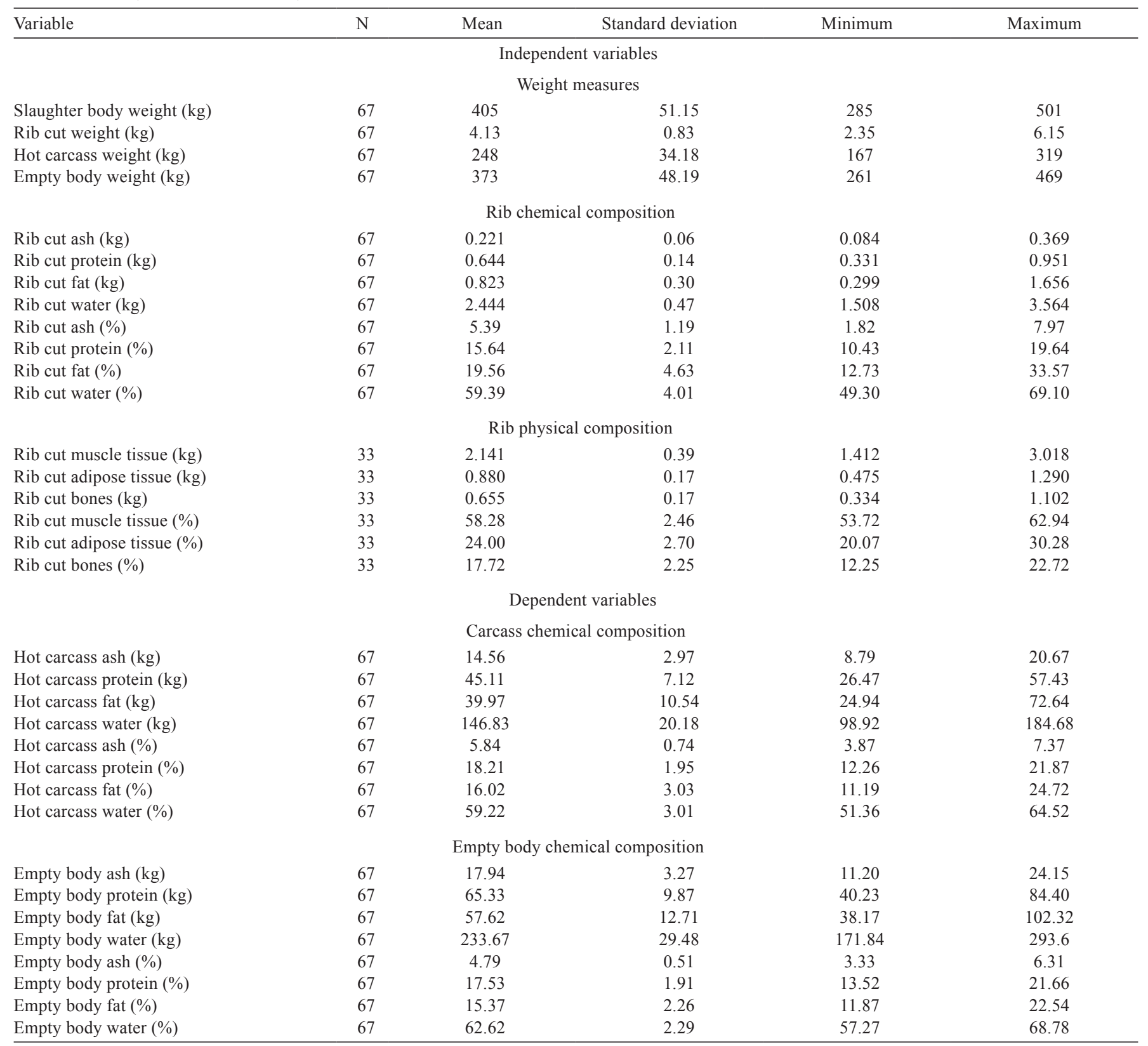


of the empty body, carcass, and rib cut was also determined indirectly to evaluate the absence of prediction biases and, consequently, the models (Table 7).

\section{Discussion}

The component that showed the widest range of variation in the rib, carcass, and empty body was fat, mainly because of the restricted-feeding group that had the fat gain influenced by the feed restriction. A similar trend was reported by Alleoni et al. (1997), Leme et al. (2000), Henrique et al. (2003), and Galati et al. (2007).

Regarding the chemical composition, although studying Santa Gertrudes animals, Henrique et al. (2003) found very similar values for the empty body composition variables $(4.24 \%$ ash, $20.04 \%$ protein, $16.17 \%$ fat, and

Table 2 - Pearson correlations (r) of carcass and empty body chemical composition, in kilogram and percentage, with the weight components, in kilogram, and rib chemical composition, in kilogram and percentage

\begin{tabular}{|c|c|c|c|c|c|c|c|c|c|c|c|c|}
\hline Variable & SBW & $\mathrm{RCW}$ & HCW & EBW & $\mathrm{RCA}$ & $\mathrm{RCP}$ & $\mathrm{RCF}$ & RCWt & RCAp & $\mathrm{RCPp}$ & RCFp & RCWtp \\
\hline $\mathrm{HCA}$ & $0.793 * *$ & $0.650 * *$ & $0.780 * *$ & $0.790 * *$ & $0.508 * *$ & $0.533 * *$ & $0.582 * *$ & $0.537 * *$ & 0.056 & -0.016 & $0.318 * *$ & $-0.375^{* *}$ \\
\hline $\mathrm{HCP}$ & $0.770 * *$ & $0.411 * *$ & $0.756 * *$ & $0.766^{* *}$ & $0.507 * *$ & $0.523 * *$ & $0.247 * *$ & $0.336 * *$ & $0.254^{*}$ & $0.310^{*}$ & -0.001 & $-0.238^{*}$ \\
\hline $\mathrm{HCF}$ & $0.677 * *$ & $0.567 * *$ & $0.682 * *$ & $0.702 * *$ & $0.386 * *$ & $0.384 * *$ & $0.788 * *$ & $0.321 * *$ & -0.038 & -0.165 & $0.703 * *$ & $-0.713 * *$ \\
\hline HCWt & $0.907 * *$ & $0.745^{* *}$ & $0.928 * *$ & $0.902 * *$ & $0.547 * *$ & $0.697 * *$ & $0.396 * *$ & $0.766 * *$ & 0.028 & 0.082 & -0.007 & -0.043 \\
\hline EBA & $0.825 * *$ & $0.588 * *$ & $0.810 * *$ & $0.818 * *$ & $0.543 * *$ & $0.544 * *$ & $0.458 * *$ & $0.500 * *$ & 0.149 & 0.095 & 0.190 & $-0.314 * *$ \\
\hline EBP & $0.736^{* *}$ & $0.324 * *$ & $0.720 * *$ & $0.730 * *$ & $0.535 * *$ & $0.542 * *$ & $0.080 * *$ & $0.282 * *$ & $0.356 * *$ & $0.457 * *$ & -0.184 & -0.134 \\
\hline $\mathrm{EBF}$ & $0.711 * *$ & $0.611 * *$ & $0.697 * *$ & $0.731 * *$ & $0.445 * *$ & $0.388 * *$ & $0.837 * *$ & $0.358 * *$ & 0.001 & -0.212 & $0.735^{* *}$ & $-0.737 * *$ \\
\hline EBWt & $0.960 * *$ & $0.801 * *$ & $0.967 * *$ & $0.958 * *$ & $0.578 * *$ & $0.700 * *$ & $0.536 * *$ & $0.770 * *$ & 0.009 & 0.009 & 0.153 & -0.1840 \\
\hline HCAp & 0.221 & 0.198 & 0.189 & 0.211 & 0.180 & 0.140 & $0.259 *$ & 0.114 & 0.049 & -0.010 & 0.207 & $-0.248^{*}$ \\
\hline HCPp & -0.143 & $-0.414 * *$ & -0.174 & -0.151 & -0.020 & -0.120 & $-0.422 * *$ & $-0.416 * *$ & $0.327 * *$ & $0.439 * *$ & $-0.341 * *$ & 0.064 \\
\hline HCFp & 0.209 & 0.200 & 0.206 & $0.240 *$ & 0.010 & 0.030 & $0.610 * *$ & -0.063 & -0.077 & -0.229 & $0.747 *$ & $-0.717 * *$ \\
\hline HCWtp & -0.209 & -0.102 & -0.181 & -0.231 & -0.151 & -0.010 & $-0.537 * *$ & 0.188 & -0.070 & 0.089 & $-0.690 * *$ & $0.770 * *$ \\
\hline EBAp & 0.233 & 0.092 & 0.211 & 0.217 & 0.201 & 0.144 & 0.044 & 0.063 & 0.168 & 0.156 & -0.020 & -0.108 \\
\hline EBPp & -0.154 & $-0.469 * *$ & -0.171 & -0.165 & 0.012 & -0.067 & $-0.613 * *$ & $-0.410 * *$ & $0.414 * *$ & $0.591 * *$ & $-0.593 * *$ & $0.248^{*}$ \\
\hline EBFp & 0.175 & 0.230 & 0.156 & 0.199 & 0.130 & -0.004 & $0.670 * *$ & -0.042 & -0.053 & $-0.325 * *$ & $0.811^{* *}$ & $-0.749 * *$ \\
\hline EBWtp & -0.186 & 0.068 & -0.161 & -0.211 & -0.185 & -0.009 & $-0.281 *$ & $0.326 * *$ & $-0.259 * *$ & -0.168 & $-0.418 * *$ & $0.649 * *$ \\
\hline
\end{tabular}

SBW - slaughter body weight (kg); RCW - rib cut weight (kg); HCW - hot carcass weight (kg); EBW - empty body weight (kg); RCA - rib cut ash (kg); RCP - rib cut protein (kg); $\mathrm{RCF}$ - rib cut fat (kg); RCWt - rib cut water (kg); RCAp - rib cut ash (\%); RCPp - rib cut protein (\%); RCFp - rib cut fat (\%); RCWtp - rib cut water (\%); HCA - hot carcass ash $(\mathrm{kg})$; HCP - hot carcass protein $(\mathrm{kg})$; HCF - hot carcass fat (kg); HCWt - hot carcass water (kg); EBA - empty body ash (kg); EBP - empty body protein (kg); EBF - empty body fat (kg); EBWt - empty body water (kg); HCAp - hot carcass ash (\%); HCPp - hot carcass protein (\%); HCFp - hot carcass fat (\%); HCWtp - hot carcass water (\%); EBAp - empty body ash (\%); EBPp - empty body protein (\%); EBFp - empty body fat (\%); EBWtp - empty body water (\%).

Correlations not followed by asterisks are nonsignificant $(\mathrm{P}>0.05)$.

$* \mathrm{P}<0.05$.

$* * \mathrm{P}<0.01$.

Table 3 - Pearson correlations (r) of carcass and empty body chemical composition, in kilogram and percentage, with physical composition of rib tissues, in kilogram and percentage

\begin{tabular}{|c|c|c|c|c|c|c|}
\hline Variable & RCMT & RCAT & $\mathrm{RCB}$ & RCMTp & RCATp & RCBp \\
\hline $\mathrm{HCA}$ & $0.516^{* *}$ & $0.459 * *$ & $0.459 * *$ & - & - & - \\
\hline HCP & $0.484 * *$ & $0.377 * *$ & $0.284 * *$ & - & - & - \\
\hline $\mathrm{HCF}$ & $0.499 * *$ & $0.762 * *$ & $0.423 *$ & - & - & - \\
\hline $\mathrm{HCWt}$ & $0.881 * *$ & $0.683 * *$ & $0.767 * *$ & - & - & - \\
\hline EBA & $0.548 * *$ & $0.517 * *$ & $0.495 * *$ & - & - & - \\
\hline EBP & $0.800 * *$ & $0.607 * *$ & $0.657 * *$ & - & - & - \\
\hline EBF & $0.456 * *$ & $0.668 * *$ & $0.402 *$ & - & - & - \\
\hline EBWt & $0.870 * *$ & $0.701 * *$ & $0.753 * *$ & - & - & - \\
\hline HCAp & - & - & - & -0.031 & 0.008 & 0.024 \\
\hline HCPp & - & - & - & 0.325 & -0.007 & $-0.346^{*}$ \\
\hline HCFp & - & - & - & $-0.461 * *$ & $0.565 * *$ & -0.175 \\
\hline HCWtp & - & - & - & 0.281 & $-0.624 * *$ & $0.443 * *$ \\
\hline EBAp & - & - & - & -0.136 & -0.026 & 0.179 \\
\hline EBPp & - & - & - & 0.055 & -0.195 & 0.174 \\
\hline EBFp & - & - & - & $-0.369 *$ & 0.302 & 0.040 \\
\hline EBWtp & - & - & - & -0.036 & -0.179 & 0.255 \\
\hline
\end{tabular}

RCMT - rib cut muscle tissue (kg); RCAT - rib cut adipose tissue (kg); RCB - rib cut bones (kg); RCMTp - rib cut muscle tissue (\%); RCATp - rib cut adipose tissue (\%); $\mathrm{RCBp}$ - rib cut bones $(\%)$; HCA - hot carcass ash $(\mathrm{kg})$; HCP - hot carcass protein $(\mathrm{kg})$; HCF - hot carcass fat (kg); HCWt - hot carcass water (kg); EBA - empty body ash $(\mathrm{kg})$; EBP - empty body protein ( $\mathrm{kg})$; EBF - empty body fat $(\mathrm{kg})$; EBWt - empty body water (kg); HCAp - hot carcass ash (\%); HCPp - hot carcass protein (\%); HCFp - hot carcass fat (\%); HCWtp - hot carcass water (\%); EBAp - empty body ash (\%); EBPp - empty body protein (\%); EBFp - empty body fat (\%); EBWtp - empty body water (\%). Correlations not followed by asterisks are nonsignificant $(\mathrm{P}>0.05)$.

$* \mathrm{P}<0.05$.

$* * \mathrm{P}<0.01$. 


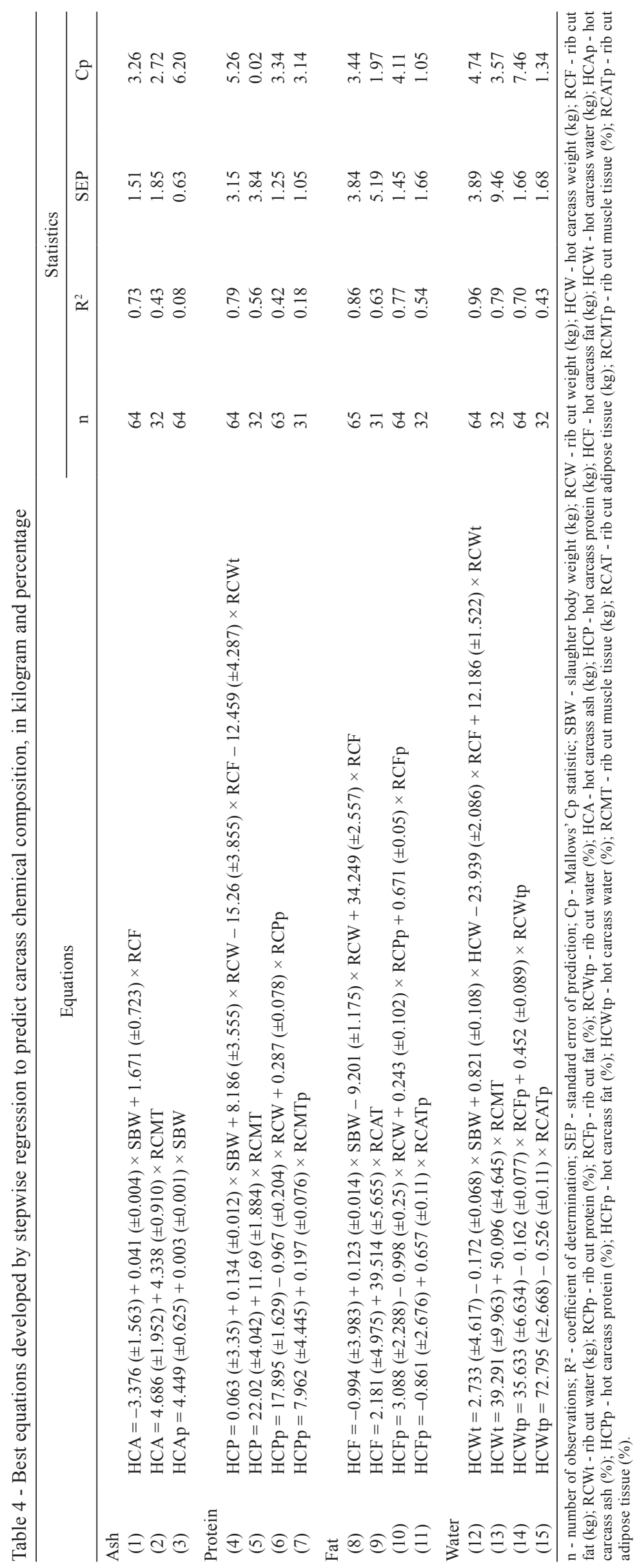




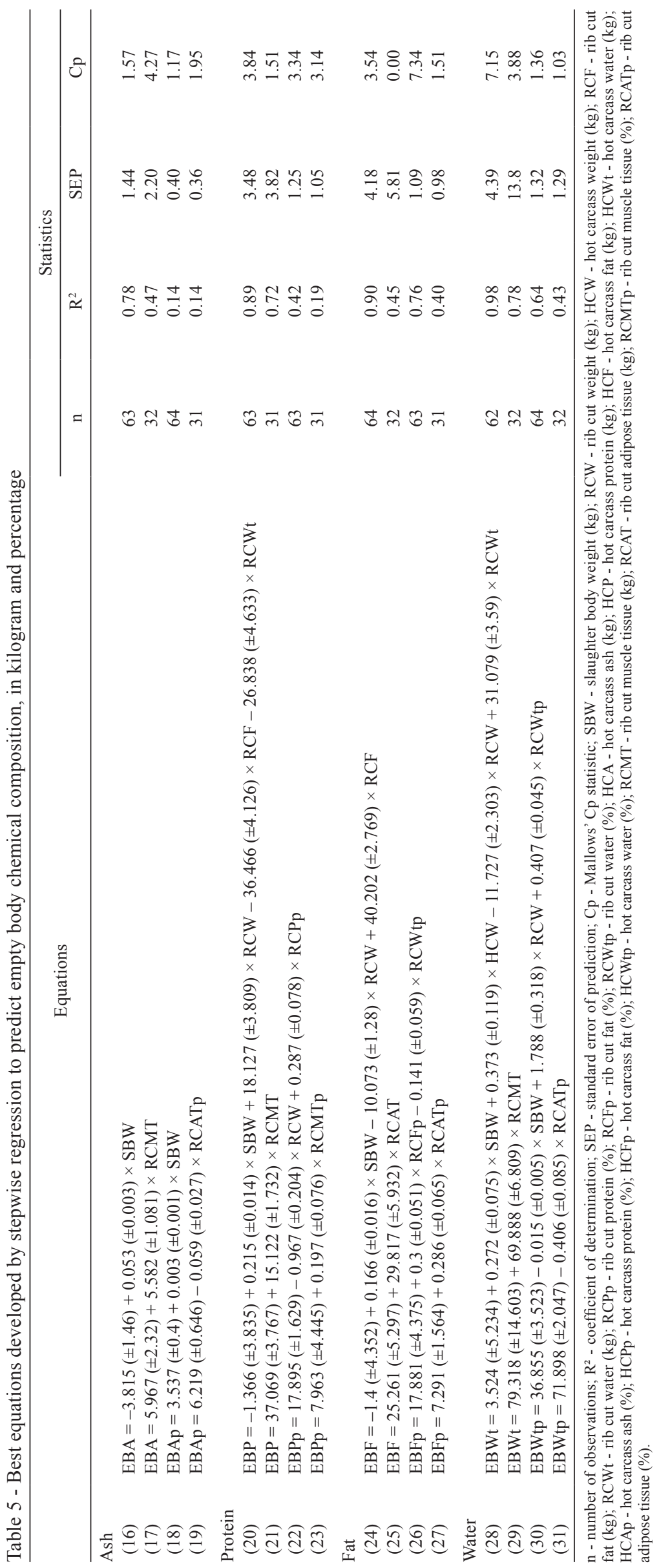


Table 6 - Mean, standard deviation, and minimum and maximum values of the variables used for validation of the models

\begin{tabular}{|c|c|c|c|c|c|}
\hline Variable & $\mathrm{N}$ & Mean & Standard deviation & Minimum & Maximum \\
\hline \multicolumn{6}{|c|}{ Weight measures } \\
\hline Slaughter body weight (kg) & 36 & 435 & 51.15 & 260 & 608 \\
\hline Rib cut weight $(\mathrm{kg})$ & 36 & 4.22 & 0.98 & 2.15 & 6.33 \\
\hline Empty body weight (kg) & 36 & 390 & 71.36 & 216 & 548 \\
\hline \multicolumn{6}{|c|}{ Rib chemical composition } \\
\hline Rib cut ash $(\mathrm{kg})$ & 36 & 0.482 & 0.15 & 0.177 & 0.868 \\
\hline Rib cut water $(\mathrm{kg})$ & 36 & 2.250 & 0.45 & 1.283 & 3.076 \\
\hline \multicolumn{6}{|c|}{ Carcass chemical composition } \\
\hline Hot carcass ash $(\mathrm{kg})$ & 36 & 14.20 & 3.08 & 9.32 & 22.83 \\
\hline Hot carcass protein $(\mathrm{kg})$ & 36 & 46.17 & 8.86 & 22.43 & 60.12 \\
\hline Hot carcass fat $(\mathrm{kg})$ & 36 & 44.18 & 17.31 & 11.93 & 76.25 \\
\hline Empty body fat $(\mathrm{kg})$ & 36 & 70.29 & 27.43 & 19.40 & 126.48 \\
\hline Empty body water (kg) & 36 & 233.88 & 34.71 & 146.28 & 307.04 \\
\hline
\end{tabular}

Table 7 - Evaluation of bias of the models selected by regressing residuals on predicted values

\begin{tabular}{|c|c|c|c|c|c|}
\hline \multirow{2}{*}{ Model } & \multicolumn{2}{|c|}{ Mean bias ${ }^{1}$} & \multicolumn{2}{|c|}{ Linear bias ${ }^{2}$} & \multirow{2}{*}{ SEP } \\
\hline & Estimate & P-value & Estimate & $\mathrm{P}$-value & \\
\hline Equation 1 & $9.317( \pm 2.314)$ & 0.0003 & $-0.697( \pm 0.14)$ & $<0.0001$ & 2.94 \\
\hline Equation 3 & $28.050( \pm 6.354)$ & $<0.0001$ & $-4.888( \pm 1.103)$ & $<0.0001$ & 1.49 \\
\hline Equation 4 & $5.855( \pm 3.999)$ & 0.1523 & $-0.189( \pm 0.79)$ & 0.0224 & 4.44 \\
\hline Equation 5 & $-22.926( \pm 7.065)$ & 0.0028 & $0.457( \pm 0.148)$ & 0.004 & 4.58 \\
\hline Equation 6 & $15.151( \pm 3.49)$ & 0.0001 & $-0.842( \pm 0.203)$ & 0.0002 & 1.68 \\
\hline Equation 8 & $-9.995( \pm 7.807)$ & 0.2091 & $0.119( \pm 0.156)$ & 0.4511 & 11.1 \\
\hline Equation 9 & $-1.52( \pm 2.419)$ & 0.534 & $-0.125( \pm 0.044)$ & 0.0072 & 4.90 \\
\hline Equation 10 & $7.688( \pm 4.886)$ & 0.1249 & $-0.497( \pm 0.278)$ & 0.0826 & 4.34 \\
\hline Equation 11 & $-2.771( \pm 1.543)$ & 0.0815 & $0.048( \pm 0.082)$ & 0.5637 & 1.89 \\
\hline Equation 12 & $59.825( \pm 12.653)$ & $<0.0001$ & $-0.373( \pm 0.085)$ & 0.0001 & 15.78 \\
\hline Equation 13 & $1.388( \pm 12.307)$ & 0.9109 & $0.007( \pm 0.082)$ & 0.9297 & 10.89 \\
\hline Equation 14 & $6.166( \pm 19.995)$ & 0.7596 & $-0.067( \pm 0.355)$ & 0.8499 & 4.52 \\
\hline Equation 19 & $-4.988( \pm 2.011)$ & 0.0182 & $1.122( \pm 0.446)$ & 0.0167 & 0.92 \\
\hline Equation 20 & $21.269( \pm 5.578)$ & 0.0006 & $-0.34( \pm 0.075)$ & $<0.0001$ & 6.85 \\
\hline Equation 21 & $-42.806( \pm 9.82)$ & 0.0001 & $0.595( \pm 0.139)$ & 0.0002 & 5.59 \\
\hline Equation 22 & $14.172( \pm 2.105)$ & $<0.0001$ & $-0.796( \pm 0.122)$ & $<0.0001$ & 1.01 \\
\hline Equation 23 & $4.251( \pm 3.618)$ & 0.2483 & $-0.265( \pm 0.198)$ & 0.1896 & 0.88 \\
\hline Equation 24 & $-25.978( \pm 12.205)$ & 0.0406 & $0.404( \pm 0.173)$ & 0.0259 & 16.27 \\
\hline Equation 25 & $-46.325( \pm 5.39)$ & $<0.0001$ & $0.850( \pm 0.083)$ & $<0.0001$ & 7.07 \\
\hline Equation 26 & $-8.066( \pm 6.152)$ & 0.1986 & $0.471( \pm 0.353)$ & 0.1918 & 3.89 \\
\hline Equation 27 & $-217.77( \pm 19.962)$ & $<0.0001$ & $29.727( \pm 2.608)$ & $<0.0001$ & 2.12 \\
\hline Equation 28 & $41.392( \pm 10.427)$ & 0.0004 & $-0.197( \pm 0.043)$ & $<0.0001$ & 10.47 \\
\hline Equation 29 & $3.52( \pm 19.545)$ & 0.8581 & $-0.004( \pm 0.084)$ & 0.9640 & 15.50 \\
\hline Equation 30 & $-44.57( \pm 24.11)$ & 0.0732 & $0.755( \pm 0.403)$ & 0.0695 & 2.88 \\
\hline
\end{tabular}

SEP - standard error of prediction.

${ }^{1}$ Mean bias is the intercept of regression of residuals (observed - predicted) on the predicted values centered on their respective means.

${ }^{2}$ Linear bias is the slope of regression of residuals (observed - predicted) on the predicted values centered on their respective means. 
$59.55 \%$ water). However, these authors obtained different values for rib chemical composition, also reported as a percentage, with a higher percentage of protein (19.74\%) than fat $(16.79 \%)$, while the opposite was observed in the present study. In contrast, the results of physical analysis of the rib $(59.2 \%$ for muscle, $21.93 \%$ for fat, and $18.87 \%$ for bones) were similar to those obtained here.

The correlations were low and generally close to zero when the chemical components of the rib, carcass, and empty body were expressed as a percentage, providing strong evidence that the parameters in percentage units are not the most favorable to be used in prediction models. However, Lanna et al. (1995), Alleoni et al. (1997), Silva et al. (2002), Henrique et al. (2003), and Paulino et al. (2005, 2009) found high correlations between chemical components of the rib and empty body, expressed as a percentage.

Slaughter body weight was the most frequently used independent variable to develop the equations for the chemical components of the carcass and empty body. This variable was included in all models, in kilogram, identified as the best models (Equations 1, 4, 8, and 12 of Table 4 and Equations 16, 20, 24, 28), demonstrating its high predictive ability.

Medium coefficients of determination were obtained for the equations used to estimate the chemical components of the carcass and empty body elaborated with the physical parameters of the rib section, when expressed as kilogram. Slaughter body weight, hot carcass weight, empty body weight, and rib cut weight were not included in these models which, therefore, exhibited poor predictive abilities.

The chemical component of the carcass and empty body that was most difficult to estimate, because the equations usually exhibited very low coefficients of determination, was ash. However, considering this difficulty, the best equations to predict carcass (Equation 1) and empty body ash (Equation 16) included slaughter body weight and rib cut fat and only slaughter weight, respectively, with coefficients of determination higher than those reported by Paulino et al. (2009) and appropriate values for Cp statistics.

Regarding carcass protein, the best model included slaughter body weight, rib cut weight, rib cut fat, and rib cut water (Equation 4). The coefficient of determination found was higher than that reported by Paulino et al. (2009) of 0.72 . The best equation to predict empty body protein also included rib cut weight, carcass weight, and rib cut fat and water (Equation 20). The coefficient of determination $\left(\mathrm{R}^{2}=0.89\right)$ was much higher than those observed by Silva et al. (2002), Paulino et al. (2009), and Marcondes et al. (2012), who reported values of 0.59, 0.75, and 0.59 , respectively.
The best equations to predict carcass fat (Equation 8) and empty body fat (Equation 24) included slaughter and rib cut weight and slaughter weight, rib cut weight and rib cut fat, respectively. The coefficient of determination of Equation 8 was high. Lower coefficients were reported by Alleoni et al. (1997) (0.853), Silva et al. (2002) (0.56), and Paulino et al. (2009) (0.81) and higher coefficients by Lanna et al. (1995) (0.95), Henrique et al. (2003) (0.92), Paulino et al. (2005) (0.93), and Marcondes et al. (2012) (0.89). Among all carcass and empty body chemical components, the best prediction models were obtained for water, providing the highest coefficients of determination. The best equation to predict carcass water (Equation 12) included the effects of slaughter body weight, hot carcass weight, and rib cut fat and water, with a coefficient of determination that was much higher than those reported by Paulino et al. (2009) and Marcondes et al. (2012), who obtained coefficients of 0.66 and 0.67 , respectively. For empty body water, the best equation (Equation 28) included the effects of slaughter body weight, rib cut weight, hot carcass weight, and rib cut water. Although this equation included many independent variables, the weight variables are easily and rapidly measured. The coefficient of determination of this equation was the same as that observed by Galati et al. (2007) and higher than that reported in all other studies compared (Lanna et al., 1995; Alleoni et al., 1997; Silva et al., 2002; Henrique et al., 2003; Paulino et al., 2005, 2009; Bonilha, 2011).

The equations were used for the independent variables of the second database, regressing residuals (observed minus predicted values) on the values predicted with the equations. According to St-Pierre (2003), the intercept of the regression equation of observed values minus predicted values on the predicted values indicates mean bias, while the angular coefficient indicates linear bias. The intercept and coefficient assume a value of zero if the model is unbiased. Centralization of the independent variable around its mean makes the intercept and angular coefficient orthogonal and, consequently, independent from one another, assuming values of $\beta_{0}=0$ and $\beta_{1}=0$ when the model is unbiased.

Applying the approach of St-Pierre (2003) to the selected models indicated mean and linear bias $(\mathrm{P}<0.05)$ for the following equations used to predict chemical composition: carcass ash in kilogram (Equation 1), carcass ash in percentage (Equation 3), carcass protein in kilogram (Equation 5), carcass protein in percentage (Equation 6), carcass fat in kilogram (Equation9), carcass water in kilogram (Equation 12), empty body ash in kilogram (Equations 16 and 17), empty body ash in percentage (Equations 18 and 19), empty body protein in kilogram (Equations 20 and 21), empty body fat in kilogram (Equations 24 and 25), 
empty body fat in percentage (Equation 27), empty body water in kilogram (Equation 28), and empty body water in percentage (Equation 31).

The model for predicting carcass protein (Equation 4) did not show mean bias ( $\mathrm{P}=0.1523)$, but exhibited statistically significant linear bias $(\mathrm{P}=0.0224)$. The magnitude of this linear bias implies a value less than $2 \mathrm{~kg}$ for the minimum predicted value of carcass protein $(28.8 \mathrm{~kg})$ and a value less than $0.6 \mathrm{~kg}$ for the maximum predicted value of carcass protein $(77.6 \mathrm{~kg})$. These values are lower than the standard error of prediction obtained by regressing residuals on the predicted values $(4.44 \mathrm{~kg})$, indicating that the linear bias of the model is not of considerable importance. In contrast, no linear or mean bias $(\mathrm{P}>0.05)$ was observed for the models used to predict carcass ash in kilogram (Equation 2), carcass protein in percentage (Equation 7), carcass fat in kilogram (Equation 8), carcass fat in percentage (Equations 10 and 11), carcass water in kilogram (Equation 13), carcass water in percentage (Equations 14 and 15), empty body protein in percentage (Equation 23), empty body fat in percentage (Equation 26), empty body water in kilogram (Equation 29), and empty body water in percentage (Equation 30), thus evaluating these models for the prediction of these components.

Despite having the highest coefficient of determination $\left(\mathrm{R}^{2}=0.98\right)$ of all models developed, Equation 28 exhibited both mean and linear bias due to the negative effect of superparameterization and the effect of collinearity between the variables slaughter body weight, hot carcass weight, and rib cut weight included in the model. The correlation between rib cut weight and hot carcass weight was 0.79 , the correlation between rib cut weight and slaughter weight was 0.76 , and the correlation between slaughter weight and hot carcass weight was 0.99 , thus explaining the effect of collinearity.

The use of stepwise regression permitted the inclusion of independent variables with good predictive ability, which would consequently improve the quality of the prediction equations for carcass and empty body composition. However, the effect of collinearity between variables and the negative effect of superparameterization may render the model biased for a specific dataset, as observed for the prediction model of empty body water in kilogram, which had the highest coefficient of determination $\left(\mathrm{R}^{2}=0.98\right)$ among all developed models, but exhibited mean and linear biases.

The models for predicting body and carcass composition expressed as kilogram were better than the models for estimating the same variable expressed as a percentage, since they had higher coefficients of determination, although the models used to predict carcass fat and water percentage and empty-body fat percentage also had good coefficients of determination $\left(\mathrm{R}^{2} \geq 0.7\right)$.

\section{Conclusions}

It is possible to estimate the chemical composition of Nellore cattle with precision and accuracy using models that include the chemical composition of the 9th-,10th-, and 11 th-rib section as independent variables. Slaughter weight is an important predictor of body and carcass composition and is included in most of the developed equations. The prediction models developed for carcass water, fat, protein, and ash and for empty body water, fat, and protein were unbiased and are, therefore, valid as an indirect method for determining these chemical components in beef cattle.

\section{Acknowledgments}

The authors thank the state funding agency Fundação de Apoio à Pesquisa do Estado de São Paulo (FAPESP, grant 2013/19205-1) for the financial support.

\section{References}

Alleoni, G. F.; Leme, P. R.; Boin, C.; Nardon, R. F.; Demarchi, J. J. A. A.; Vieira, P. F. and Tedeschi, L. O. 1997. Avaliação da composição química e física dos cortes de costela para estimar a composição química corporal de novilhos Nelore. Revista Brasileira de Zootecnia 26:382-390.

AOCS - American Oil Chemists' Society. 2009. Official methods and recommended practices of the AOCS. 6th ed. AOCS, Denver.

Bonilha, S. F. M.; Packer, I. U.; Figueiredo, L. A.; Alleoni, G. F.; Resende, F. D.; and Razook, A. G. 2007. Efeitos da seleção para peso pós-desmame sobre características de carcaça e rendimento de cortes cárneos comerciais de bovinos. Revista Brasileira de Zootecnia 36:1275-1281.

Bonilha, S. F. M.; Tedeschi, L. O.; Packer, I. U.; Razook, A. G.; Nardon, R. F.; Figueiredo, L. A. and Alleoni, G. F. 2011. Chemical composition of whole body and carcass of Bos indicus and tropically adapted Bos taurus breeds. Journal of Animal Science 89:2859-2866.

De Paula, N. F.; Tedeschi, L. O.; Paulino, M. F.; Fernandes, H. J.; and Fonseca, M. A. 2013. Predicting carcass and body fat composition using biometric measurements of grazing beef cattle. Journal of Animal Science 91:3341-3351.

Efroymson, M. A. 1960. Multiple Regression Analysis, p.191-203. In: Mathematical methods for digital computers. Ralston, A. and Wilf, H. S., eds. John Wiley, New York.

Galati, R. L.; Ezequiel, J. M. B.; Silva, G. C.; Watanabe, P. H.; Santos, V. C. and Biagioli, B. 2007. Equações de predição da composição química corporal a partir do corte da $9-10-11^{\text {a }}$ costelas de bovinos castrados Nelore. Revista Brasileira de Zootecnia 36:480-488.

Hankins, O. G. and Howe, P. E. 1946. Estimation of the composition of beef carcasses and cuts. Technical Bulletin 926. p.1-19. United States Department of Agriculture - USDA, Washington, D.C., USA. 
Henrique, W.; Sampaio, A. A. M.; Leme, P. R.; Alleoni, G. F. and Lanna, D. P. D. 2003. Estimativa da composição química corporal de tourinhos Santa Gertrudes a partir da composição química e física das 9-10-11 ${ }^{\mathrm{a}}$ costelas. Revista Brasileira de Zootecnia 32:709-718.

Lanna, D. P. D.; Boin, C.; Alleoni, G. F.; and Leme, P. R. 1995. Estimation of carcass and empty body composition of Zebu bulls using the composition of rib cuts. Scientia Agricola 52:189-197.

Leme, P. R.; Lanna, D. P. D.; Henrique, W.; Alleoni, G. F. and Boin, C. 2000. Substituição do grão de milho por polpa de citros em dietas com diferentes níveis de concentrado. 2. Taxas de deposição e composição química corporal. Revista Brasileira de Zootecnia 29:834-839.

MacNeil, M. D. 1983. Choice of a prediction equation and the use of the selected equation in subsequent experimentation. Journal of Animal Science 57:1329-1336.

Mallows, C. L. 1973. Some comments on $\mathrm{C}_{\mathrm{p}}$. Technometrics 15:661-675.

Marcondes, M. I.; Tedeschi, L. O.; Valadares Filho, S. C. and Chizzotti, M. L. 2012. Prediction of physical and body compositions of purebred and crossbred Nellore cattle using the composition of a rib section. Journal of Animal Science 90:1280-1290.

Paulino, P. V. R; Costa, M. A. L.; Valadares Filho, S. C.; Paulino, M. F.; Valadares, R. F. D.; Magalhães, K. A.; Detmann, E.; Porto, M. O. and Moraes, K. A. K. 2005. Validação das equações desenvolvidas por Hankins e Howe para predição da composição da carcaça de Zebuínos e desenvolvimento de equações para estimativa da composição corporal. Revista Brasileira de Zootecnia 34:327-339.

Paulino, P. V. R.; Valadares Filho, S. C.; Detmann, E.; Valadares, R. F. D.; Fonseca, M. A. and Marcondes, M. I. 2009. Deposição de tecidos e componentes químicos corporais em bovinos Nelore de diferentes classes sexuais. Revista Brasileira de Zootecnia 38:2516-2524.

Silva, F. F.; Valadares Filho, S. C.; Ítavo, L. C. V.; Veloso, C. M.; Valadares, R. F. D.; Cecon, P. R.; Paulino, P. V. R. and Moraes, E. H. B. K. 2002. Composição corporal e requisitos energéticos e protéicos de bovinos Nelore, não-castrados, alimentados com rações contendo diferentes níveis de concentrado e de proteína. Revista Brasileira de Zootecnia 31:503-513.

St-Pierre, N. R. 2003. Reassessment of biases in predicted nitrogen flows to the duodenum by NRC 2001. Journal of Dairy Science $86: 344-350$. 